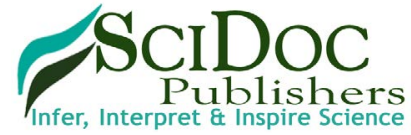

International Journal of Clinical Dermatology \& Research (IJCDR) ISSN 2332-2977

\title{
Plasma Lipid Profile Parameters and Their Internal Ratios in Clinically Sub - Grouped Psoriasis Patients
}

Srinivas S, Goudappala P, Kashinath RT

Subbaiah Institute of Medical Sciences, Karnataka, India.

\section{Abstract}

Psoriasis is a common chronic inflammatory skin disease been considered in the recent days by dermatologists as a systemic disease with multi organ abnormalities. Increase risk of cardiovascular complications is associated with psoriasis due to an underlying dyslipidemia. A study was planned to assess the plasma lipid profile parameters and their internal ratios to assess their relationship to cardiovascular risk. A total number of 100 subjects including 50 normal control subjects and 50 psoriasis patients were studied. The psoriasis patients were clinically sub grouped into Mild (Group-1), Moderate (Group-2) and Severe (Group-3). A fasting blood sample was collected from normal control subjects and psoriasis patients for the analysis of Total cholesterol, triacylglycerol and HDL cholesterol. The levels of VLDLC, LDLC and their internal ratios was calculated. Results shows that Total cholesterol, Triacylglycerols are elevated in psoriasis patients whereas HDLC level was decreased. The ratio Triacylglycerol/HDLC was significantly elevated in psoriasis patients as well as a proportionate elevation observed in severity based psoriasis sub grouped patients suggesting this ratio may be useful in assessing cardiovascular risk in psoriasis patients.

Keywords: Psoriasis; PASI Score; Total Cholesterol; Triacylglycerol; Cardiovascular Risk and TAG/HDLC.

Abbreviations: OPD: Outpatient Department; TC: Total Cholesterol; TAG: Triacylglycerols; VLDLC: Very Low Density Lipoprotein Cholesterol; LDLC: Low Density Lipoprotein Cholesterol; HDLC: High Density Lipoprotein Cholesterol; AC: Atherogenic Coefficient; AIP: Atherogenic Index of Plasma.

\section{Introduction}

Psoriasis, a chronic dermatological syndrome with a population prevalence of $2-3 \%$ and its prevalence is affected by genetic, environmental, viral, immunological, biochemical, endocrinological and psychological factors as well as alcohol and drug abuse. It is a common disease affecting approximately about 120-180 million people across the globe [1]. It has been recognised in the recent years that psoriasis is a systemic disease associated with multi organ abnormalities and complications [2].

One of the principle co-abnormalities seen in psoriasis patients is dyslipidemia and in this disease generally lipid metabolism and lipid turnover seem to be altered due to an underlying cardiovascular involvement as well as due to underlying psychological stress. It has been observed by many research workers that plasma lipid levels are altered in psoriasis patients [3-18].
Psoriatic dyslipidemia is particularly characterised by significant raises in total cholesterol levels as well as in triacylglycerols levels $[9,13-15,17]$, also as these two lipid parameters are claimed to be involved in cardiovascular complications, hence psoriasis patients are more prone to cardiovascular diseases due to this lipid derangement.

Though there are reports available to show the abnormal plasma lipid levels in psoriasis patients but the reports regarding to show the relationship of plasma lipid parameters with the severity of the disease as well as the internal reciprocals of these lipid parameters with the severity of the disease in clinically sub grouped psoriasis patients are few. Hence a study was planned to assess the plasma lipid profile parameters and their internal ratios in clinically sub grouped psoriasis patients with an emphasis on the clinical utility of these lipid parameters and their ratio in assessing the

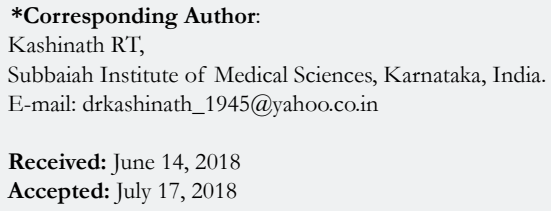

Citation: Srinivas S, Goudappala P, Kashinath RT. Plasma Lipid Profile Parameters and Their Internal Ratios in Clinically Sub - Grouped Psoriasis Patients. Int J Clin Dermatol Res. 2018;6(4):174-179. doi: http://dx.doi.org/10.19070/2332-2977-1800040

Copyright: Kashinath RT ${ }^{\circ}$ 2018. This is an open-access article distributed under the terms of the Creative Commons Attribution License, which permits unrestricted use, distribution and reproduction in any medium, provided the original author and source are credited. 
cardiovascular risk in these patients.

\section{Materials and Methods}

The psoriasis patients attending dermatology outpatient department (OPD) of Subbaiah Medical College Hospital and other associated hospitals attached to Subbaiah Institute of Medical Sciences, NH-13, Purale, Shivamogga, were selected. Detailed history, regarding the illness, duration of disease, the drugs taken as well as food habits was collected. The normal control subjects were taken from the employees of Medical College and affiliated hospitals. Psoriasis patients are clinically sub-grouped into Mild, Moderate and Severe depending on their PASI Scores.

PASI Score is a mathematically derived score to assess the severity of psoriasis depending on the appearance and distribution of psoriatic lesions on different parts of the body like a.Head(h), b.Upper Limbs(u), c. Trunk(t) and d.Lower Limbs(d). While calculating PASI Score the sites of affection i.e, Head, Upper limbs, Trunk and Lower limbs are separately scored. Morphologic scoring of psoriasis plaques is done by evaluation of parameters like Erythema (E), Induration (I) and Desquamation (D). Each of these parameters are graded on a severity scale.

Since the four body region (Head, Upper limbs, Trunk and Lower limbs ) represent about $10 \%, 20 \%, 30 \%$ and $40 \%$ of body surface area respectively hence they are given corresponding weightage in scoring by multiplying their scores by $0.1,0.2,0.3$ and 0.4 respectively. Hence the final formula [19] at arriving PASI Score is :

PASI $=0.1 \times(E h+I h+D h) A+0.2 \times(E u+I u+D u) A+0.3$ $\mathrm{x}(\mathrm{Et}+\mathrm{It}+\mathrm{Dt}) \mathrm{A}+0.4 \mathrm{x}(\mathrm{El}+\mathrm{Il}+\mathrm{Dl}) \mathrm{A}$.
A fasting heparinised blood sample $(5-7 \mathrm{ml})$ was collected from selected psoriasis patients as well as from chosen normal control subjects after obtaining an informed consent. The blood samples were centrifuged at $3500 \mathrm{rpm}$ for ten minutes. The separated plasma was employed for estimation of Total Cholesterol, Triacylglycerols and HDL Cholesterol [20-22].

\section{Statistical Analysis}

The data obtained were expressed as their Mean \pm SD and the statistical significance was calculated using student t-test. $\mathrm{p}<0.05$ was considered as significant.

\section{Results and Discussions}

The present study was carried out jointly by the Dept. of Dermatology and Dept. R\&D during the period from November 2017 June 2018. The study included a total number of 100 subjects including 50 normal control and 50 psoriasis patients. The psoriasis patients were clinically sub grouped as per their PASI Score:

Group-1 (Mild Psoriasis) : $\quad: 3$

Group-2 (Moderate Psoriasis) : 3.0-6.0

Group-3 (Severe Psoriasis) : : $>6.1$

Group-1 was having 11 patients, Group-2 consists 17 patients and Group-3 had 22 patients.

Table-1 shows the plasma levels of Total Cholesterol ( TC), Triacylglycerols (TAG), Very low density lipoprotein cholesterol (VLDLC), Low density lipoprotein cholesterol (LDLC), High density lipoprotein cholesterol (HDLC) levels in normal control

Table 1. Showing the plasma levels of Total Cholesterol(TC), Triacylglycerols (TAG),VLDL Cholesterol, LDL Cholesterol and HDL Cholesterol levels in normal control subjects as well as in psoriasis patients.

\begin{tabular}{|c|c|c|c|c|c|}
\hline Groups & $\begin{array}{c}\text { Total Cholesterol } \\
(\mathbf{m g} / \mathbf{d} \mathbf{l})\end{array}$ & $\begin{array}{c}\text { Triacylglycerols } \\
\mathbf{( m g / d l )}\end{array}$ & $\begin{array}{c}\text { VLDLC } \\
\mathbf{( m g} / \mathbf{d} \mathbf{l})\end{array}$ & $\begin{array}{c}\text { HDLC } \\
(\mathbf{m g} / \mathbf{d l})\end{array}$ & $\begin{array}{c}\text { LDLC } \\
(\mathbf{m g} / \mathbf{d l})\end{array}$ \\
\hline Normal Subjects(50) & $161.86 \pm 31.82$ & $114.64 \pm 32.21$ & $28.35 \pm 9.08$ & $58.27 \pm 8.68$ & $104.86 \pm 20.28$ \\
\hline Psoriasis Subjects (50) & $214.85 \pm 28.12^{* * *}$ & $247.78 \pm 22.16^{* * *}$ & $50.70 \pm 11.12^{* * *}$ & $45.52 \pm 9.38^{* * *}$ & $123.85 \pm 17.28 * * *$ \\
\hline
\end{tabular}

Note:

1. The values expressed are in mean $\pm \mathrm{SD}$.

2. The number in parenthesis indicates the number of subjects.

3. Probability $* \mathrm{p}<0.01, * * \mathrm{p}<0.05$ and $* * * \mathrm{p}<0.001$.

Table 2. Showing the plasma levels of Total Cholesterol(TC), Triacylglycerols(TAG), VLDL Cholesterol, LDL Cholesterol and HDL Cholesterol levels in Group-1, Group-2, Group-3 psoriasis patients.

\begin{tabular}{|c|c|c|c|c|c|}
\hline Groups & $\begin{array}{c}\text { Total Cholesterol } \\
\text { (mg/dl) }\end{array}$ & $\begin{array}{c}\text { Triacylglycerols } \\
\text { (mg/dl) }\end{array}$ & $\begin{array}{c}\text { VLDL } \\
(\mathbf{m g} / \mathbf{d l})\end{array}$ & $\begin{array}{c}\text { HDL } \\
(\mathbf{m g} / \mathbf{d l})\end{array}$ & $\begin{array}{c}\text { LDL } \\
(\mathbf{m g} / \mathbf{d l})\end{array}$ \\
\hline Group-1 (Mild) (11) & $142.68 \pm 18.18$ & $110.16 \pm 22.13$ & $20.18 \pm 6.16$ & $56.16 \pm 16.16$ & $100.66 \pm 21.22$ \\
\hline Group-2 (Moderate)(17) & $172.12 \pm 14.12^{* * *}$ & $152.26 \pm 18.18^{* * *}$ & $36.63 \pm 7.12^{* * *}$ & $49.13 \pm 15.12$ & $112.12 \pm 18.12$ \\
\hline Group-3 (Severe)(22) & $208.36 \pm 20.12^{* * *}$ & $242.16 \pm 24.14^{* * *}$ & $49.12 \pm 16.18^{* *}$ & $43.12 \pm 16.16$ & $122.8 \pm 16.16^{*}$ \\
\hline
\end{tabular}

Note

1. The values expressed are in mean $\pm \mathrm{SD}$.

2. The number in parenthesis indicates the number of subjects.

3. Probability ${ }^{*} \mathrm{p}<0.01,{ }^{* *} \mathrm{p}<0.05$ and $* * * \mathrm{p}<0.001$. 
subjects and in psoriasis patients. It is evident from the table that TC, TAG, VLDLC, and LDLC levels are significantly elevated in psoriasis patients as compared to normal control subjects whereas a significant fall is seen in HDLC levels in psoriasis patients as compared to normal control subjects.

Table-2 narrates the plasma levels lipid profile parameters - TC, TAG, VLDLC, LDLC, HDLC levels in Group-1, Group-2 and in Group-3 psoriasis patients. It is seen from the table that the lipid profile parameters except the HDLC are significantly elevated in Group-3 as compared Group-1 and Group-2, In Group-2 as compared to Group 1 as well as in Group 3 as compared to Group 2. Further it is evident from the table that there is a psoriasis disease severity related parallel raise in TC levels and TAG levels in these studied three groups of psoriasis patients.

Table- 3 gives the calculated ratios of TC/TAG, TC/HDLC, TC/ LDLC, TC/VLDLC, HDLC/LDLC, TAG/HDLC, TAG/LDLC and LDLC/VLDLC in normal control subjects and in psoriasis patients. It is evident from the table that TC/HDLC, TC/LDLC, TAG/HDLC, TAG/LDLC are significantly elevated in psoria- sis patients as compared to normal control subjects whereas the ratios TC/TAG, TC/VLDLC, HDLC/LDLC, HDLC/VLDLC and LDLC/VLDLC are significantly lowered in psoriasis patients as compared to normal control subjects. The elevation in TAG/ HDLC is much significant $(1.86 \pm 0.28$ in normal controls against $5.42 \pm 0.78$ in psoriasis patients) indicating the possibility that this ratio may be employed as a cardiovascular disease marker in Psoriasis.

Table-4 narrates the ratios of TC/TAG, TC/HDLC, TC/LDLC, TC/VLDLC, TAG/HDLC, TAG/LDLC and LDLC/VLDLC in Group-1, Group-2 as well as in Group3 psoriasis patients. It is seen from the table that there is parallel rise in the ratios of TC/ HDLC, TAG/HDLC, TAG/LDLC with the severity of disease whereas a significant parallel decrease in the ratios of TC/TAG, TC/VLDLC, HDLC/LDLC, HDLC/VLDLC and LDLC/ VLDLC with the severity of disease. Further the rise in the ratio of TAG/HDLC is so profound with the severity of psoriasis disease that it is possible to use this ratio as a marker of psoriasis disease severity.

Table 3. Showing the ratios of TC/TAG, TC/HDL, TC/LDL, TC/VLDL, HDL/LDL, HDL/VLDL, TAG/HDL, TAG/ LDL and LDL/VLDL in normal control subjects and in psoriasis patients.

\begin{tabular}{|c|c|c|c|c|c|c|c|c|c|}
\hline$\frac{\text { Parameters } \rightarrow}{\text { Groups } \downarrow}$ & $\begin{array}{l}\text { TC/ } \\
\text { TAG }\end{array}$ & $\begin{array}{l}\text { TC/ } \\
\text { HDL }\end{array}$ & $\begin{array}{l}\text { TC/ } \\
\text { LDL }\end{array}$ & $\begin{array}{l}\text { TC/ } \\
\text { VLDL }\end{array}$ & $\begin{array}{l}\text { HDL/ } \\
\text { LDL }\end{array}$ & $\begin{array}{l}\text { HDL/ } \\
\text { VLDL }\end{array}$ & $\begin{array}{l}\text { TAG/ } \\
\text { HDL }\end{array}$ & $\begin{array}{l}\text { TAG/ } \\
\text { LDL }\end{array}$ & $\begin{array}{l}\text { LDL/ } \\
\text { VLDL }\end{array}$ \\
\hline $\begin{array}{l}\text { Normal control } \\
\text { subjects }(50)\end{array}$ & $\begin{array}{c}1.36 \\
\pm \\
0.09 \\
\end{array}$ & $\begin{array}{c}2.65 \\
\pm \\
0.66\end{array}$ & $\begin{array}{c}1.51 \\
\pm \\
0.02\end{array}$ & $\begin{array}{c}5.95 \\
\pm \\
0.92 \\
\end{array}$ & $\begin{array}{c}0.49 \\
\pm \\
0.08 \\
\end{array}$ & $\begin{array}{c}2.10 \\
\pm \\
0.45 \\
\end{array}$ & $\begin{array}{c}1.86 \\
\pm \\
0.28\end{array}$ & $\begin{array}{c}0.95 \\
\pm \\
0.22 \\
\end{array}$ & $\begin{array}{c}3.52 \\
\pm \\
0.82\end{array}$ \\
\hline $\begin{array}{l}\text { Psoriasis patients } \\
\qquad(50)\end{array}$ & $\begin{array}{c}0.86 \\
\pm \\
0.05 * * *\end{array}$ & $\begin{array}{c}4.92 \\
\pm \\
0.88^{* * *}\end{array}$ & $\begin{array}{c}1.73 \\
\pm \\
0.02^{* * *}\end{array}$ & $\begin{array}{c}4.34 \\
\pm \\
0.54 * * *\end{array}$ & $\begin{array}{c}0.37 \\
\pm \\
0.03^{* * *}\end{array}$ & $\begin{array}{c}0.89 \\
\pm \\
0.02 * * *\end{array}$ & $\begin{array}{c}5.42 \\
\pm \\
0.78^{* * *}\end{array}$ & $\begin{array}{c}1.90 \\
\pm \\
0.34^{* * *}\end{array}$ & $\begin{array}{c}2.36 \\
\pm \\
0.38^{* * *}\end{array}$ \\
\hline
\end{tabular}

Note

1. The values expressed are in mean $\pm \mathrm{SD}$.

2. The number in parenthesis indicates the number of subjects.

3. Probability ${ }^{*} \mathrm{p}<0.01,{ }^{* *} \mathrm{p}<0.05$ and ${ }^{* * *} \mathrm{p}<0.001$.

Table 4. Showing the ratios of TC/TAG, TC/HDL, TC/VLDL, HDL/LDL, HDL/VLDL, TAG/HDL, TAG/LDL and LDL/VLDL in Group-1, Group-2 as well as in Group-3 Psoriasis patients.

\begin{tabular}{|c|c|c|c|c|c|c|c|c|c|}
\hline $\begin{array}{c}\text { Parameters } \rightarrow \\
\text { Groups } \downarrow\end{array}$ & $\begin{array}{l}\text { TC/ } \\
\text { TAG }\end{array}$ & $\begin{array}{l}\text { TC/ } \\
\text { HDL }\end{array}$ & $\begin{array}{l}\text { TC/ } \\
\text { LDL }\end{array}$ & $\begin{array}{c}\text { TC/ } \\
\text { VLDL }\end{array}$ & $\begin{array}{c}\text { HDL/ } \\
\text { LDL }\end{array}$ & $\begin{array}{l}\text { HDL/ } \\
\text { VLDL }\end{array}$ & $\begin{array}{l}\text { TAG/ } \\
\text { HDL }\end{array}$ & $\begin{array}{c}\text { TAG/ } \\
\text { LDL }\end{array}$ & $\begin{array}{l}\text { LDL/ } \\
\text { VLDL }\end{array}$ \\
\hline Group-1 (11) & $\begin{array}{c}1.29 \\
\pm \\
0.09\end{array}$ & $\begin{array}{c}2.55 \\
\pm \\
0.58\end{array}$ & $\begin{array}{c}1.42 \\
\pm \\
0.09\end{array}$ & $\begin{array}{c}7.10 \\
\pm \\
1.64\end{array}$ & $\begin{array}{c}0.55 \\
\pm \\
0.04\end{array}$ & $\begin{array}{c}2.74 \\
\pm \\
0.08\end{array}$ & $\begin{array}{c}1.92 \\
\pm \\
0.16\end{array}$ & $\begin{array}{c}1.12 \\
\pm \\
0.06\end{array}$ & $\begin{array}{c}4.90 \\
\pm \\
0.42\end{array}$ \\
\hline Group-2(17) & $\begin{array}{c}1.12 \\
\pm \\
0.04 * * *\end{array}$ & $\begin{array}{c}3.52 \\
\pm \\
0.96^{* * *}\end{array}$ & $\begin{array}{c}1.52 \\
\pm \\
0.86\end{array}$ & $\begin{array}{c}4.70 \\
\pm \\
0.72^{* * *}\end{array}$ & $\begin{array}{c}0.42 \\
\pm \\
0.06^{* * *}\end{array}$ & $\begin{array}{c}1.36 \\
\pm \\
0.21^{* * *}\end{array}$ & $\begin{array}{c}3.06 \\
\pm \\
0.88^{* * *}\end{array}$ & $\begin{array}{c}1.32 \\
\pm \\
0.55\end{array}$ & $\begin{array}{c}3.05 \\
\pm \\
0.08^{* * *}\end{array}$ \\
\hline Group-3(22) & $\begin{array}{c}0.82 \\
\pm \\
0.04^{* * *}\end{array}$ & $\begin{array}{c}4.86 \\
\pm \\
1.82^{* * *}\end{array}$ & $\begin{array}{c}1.66 \\
\pm \\
0.08\end{array}$ & $\begin{array}{c}4.40^{* * *} \\
\pm \\
1.01\end{array}$ & $\begin{array}{c}0.33 \\
\pm \\
0.09^{* * *}\end{array}$ & $\begin{array}{c}0.85 \\
\pm \\
0.05^{* * *}\end{array}$ & $\begin{array}{c}5.60 \\
\pm \\
1.87^{* * *}\end{array}$ & $\begin{array}{c}1.96 \\
\pm \\
0.07\end{array}$ & $\begin{array}{c}2.23 \\
\pm \\
0.86^{* * *}\end{array}$ \\
\hline
\end{tabular}

Note

1. The values expressed are in mean $\pm \mathrm{SD}$.

2. The number in parenthesis indicates the number of subjects.

3. Probability $*_{\mathrm{p}}<0.01,{ }^{* *} \mathrm{p}<0.05$ and ${ }^{* * *} \mathrm{p}<0.001$. 
Figure 1. Showing the distribution of psoriasis patients.

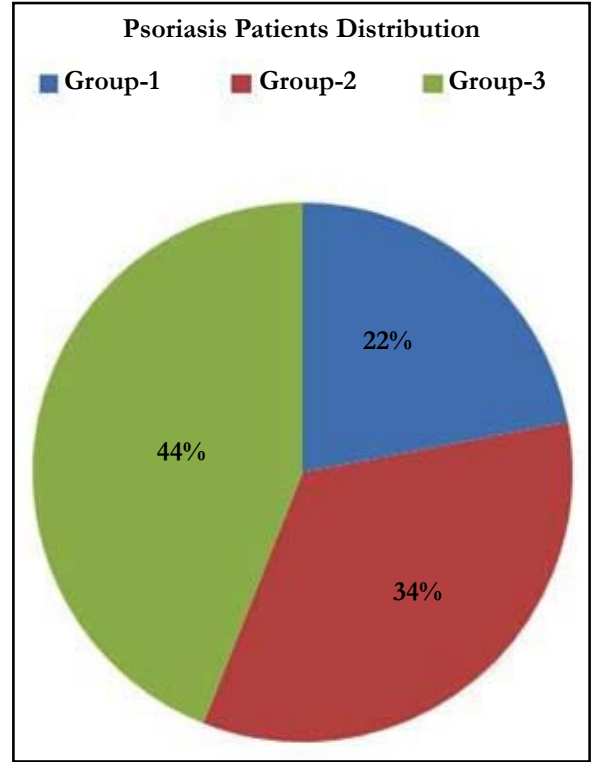

Figure 2a. Showing the comparison of TAG/HDLC in normal and psoriasis patients.

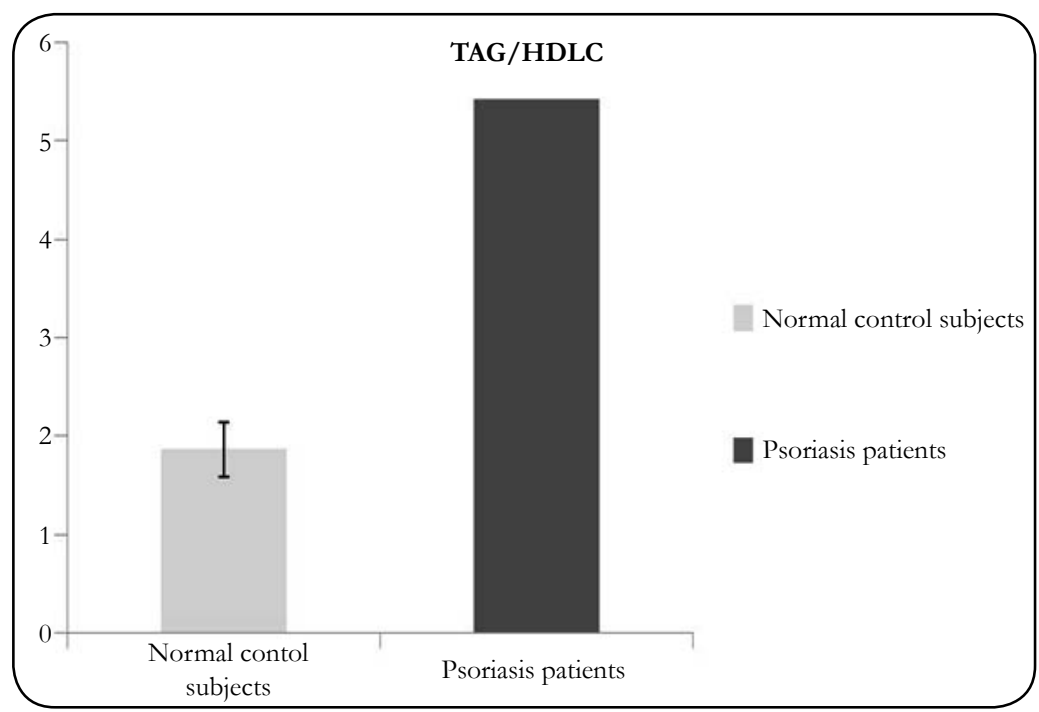

Figure 2b. Showing comparison of TAG/HDLC in clinically sub grouped psoriasis patients.

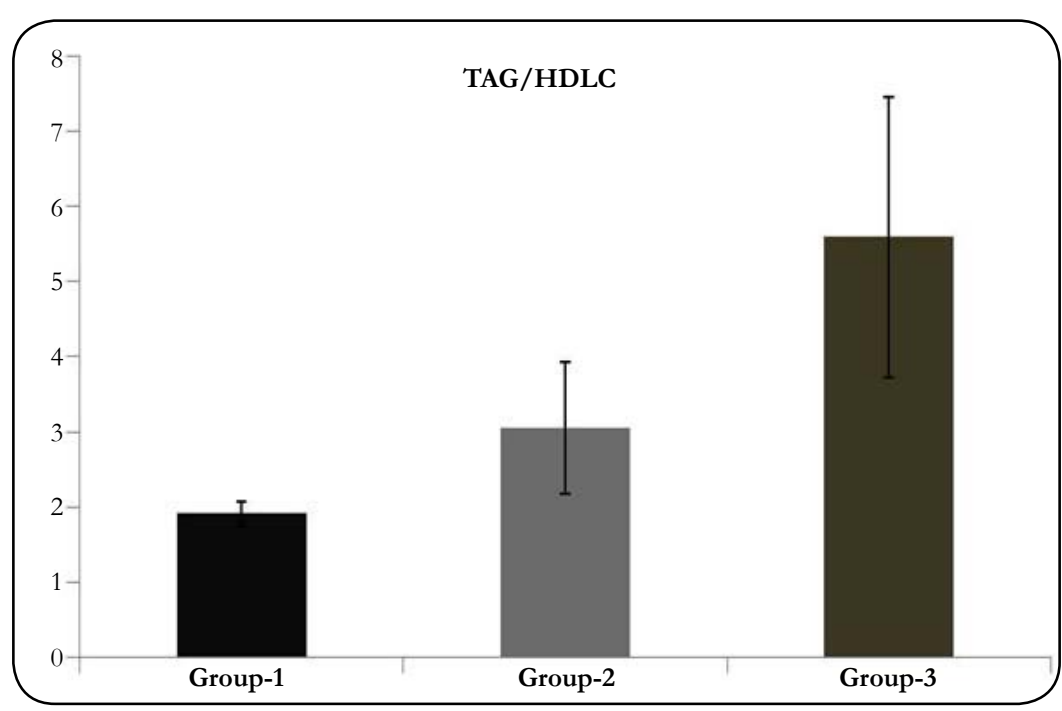


The distribution of psoriasis patients among the three groupsGroup-1(Mild), Group-2 (Moderate) and Group-3 are depicted in Figure-1.

Figure-2 gives the bar graphs showing the comparison of the ratio TAG/HDLC in normal control subjects (Figure-2a) as well as between Group 1, Group 2 and Group 3 psoriasis patients (Figure-2b). It is evident from the Figure-2 that there is a significant raise in the ratio of TAG/HDLC in psoriasis patients as well as a proportionate raise in this ratio corresponding to the disease severity.

Lipid metabolism and lipid turnover seems to be affected in psoriasis as psoriasis is primarily an inflammatory disease and normally inflammatory conditions do induce the releases of various cell signalling compounds including cytokines, interlukins, tissue necrotic factors and others [23-28], which tend to enhance systemic lipid and cholesterol synthesis through stimulating SREBP target genes as well as through up gradation of HMG CoA reductase gene $[29,30]$. This causes an increase in the systemic synthesis of lipid and cholesterol which is need of inflammatory state for the additional lipid requirements.

Psoriatic dyslipidemia, is characterised by elevated plasma triacylglycerol, cholesterol and other lipoprotein fractions [31, 32]. It is observed in the present study that there is a significant raise in plasma TAG as well as in plasma TC levels in psoriasis patients as compared to normal control subjects suggesting that dyslipidemia observed in these psoriasis patients is due to raise in TAG and TC levels or to an alteration in lipoprotein fractions involved in their transport. This is in agreement with many earlier reports [6, $8,9]$. Further the elevations in plasma lipid parameters observed in present study in psoriasis patients as well as in clinically sub grouped psoriasis patients is in agreement with studies of Mohammed Amer et al., [33].

As cardiovascular risk factors are elevated in psoriasis making these patients more vulnerable for the risk of developing cardiovascular complications. No doubt there exist an independent relationship between HDLC and cardiovascular risk however the contribution of TAG to cardiovascular risk cannot be neglected.

Cardiovascular complications including atherosclerosis is a multi factorial process, but abnormalities in plasma as well as dyslipidemia are one of the major key factors in development of cardiovascular complications [34]. The cholesterol and the triacylglycerols are two principle lipid constituents that make up the composition of lipoproteins, the salient lipid transporting particles in human system. The endogenous or liver synthesized triacylglycerols are mainly transported by lipoprotein VLDL, where as cholesterol being transported by both LDL and HDL lipoprotein fractions, further the LDL arises from VLDL fraction. Thus it becomes significant in dyslipidemia to study and to assess the composition of these two lipoproteins.

The development of cardiovascular disease is normally predicted by many atherogenic indices and the most generally employed are: Atherogenic Coefficient (AC) and Atherogenic Index of Plasma (AIP). The principle contributors of psoriatic dyslipidemia being TC as well as TAG and these are transported in blood plasma by VLDL, LDL and HDL respectively. So it becomes significant that the ratio of these parameters, specifically, the Triacylglycerols
(TAG) and the HDL Cholesterol (HDLC), may become better markers of psoriatic dyslipidemia. It has been shown recently in dyslipidemia induced cardiovascular disease the various cholesterol fractions and their internal relationships serves as better markers of cardiovascular risk [35], Hence, in the present study, TAG/HDLC was taken to assess the dyslipidemia induced cardiovascular risk in psoriasis patients. The ratio TAG/HDLC is significantly elevated in psoriasis patients as compared to normal control subjects and also a proportional elevation has been observed depending on the severity of the disease(Figure-2a and 2b) indicating its significance in assessing the cardiovascular risk in psoriasis induced dyslipidemia.

\section{Acknowledgements \& Declarations}

The authors are indebted to the Management and Principal of Subbaiah Institute of Medical Sciences, Purale, Shivamogga for their facilities support and encouragement.

\section{Conclusion}

It can be concluded from the results obtained in the present study that psoriasis patients are vulnerable group for the dyslipidemia induced cardiovascular complications and the ratio TAG/HDLC is quite promising marker of the cardiovascular complications in psoriasis. Further the results indicate that the ratio TAG/HDLC is a good marker of psoriasis disease severity. Future research work involving more number of psoriasis patients with various cardiac markers throw much light on this aspect.

\section{References}

[1]. Icen M, Crowson CS, McEvoy MT, Dann FJ, Gabriel SE, Kremers HM. Trends in incidence of adult-onset psoriasis over three decades: a population-based study. J Am Acad Dermatol. 2009 Mar;60(3):394-401. doi: 10.1016/j.jaad.2008.10.062. PubMed PMID: 19231638.

[2]. Pietrzak A, Michalak-Stoma A, Chodorowska G, Szepietowski JC. Lipid disturbances in psoriasis: an update. Mediators Inflamm. 2010;2010. doi: 10.1155/2010/535612. PubMed PMID: 20706605.

[3]. Chibowska M. Role of serum lipids in pseriasis. Przegl Dermatol. 1970 Mar-Apr;57(2):255-60. PubMed PMID: 4912560.

[4]. Pietrzak A, Toruniowa B, Pietrzak B, Chwaluk J. Lipid profile in psoriatic patients according to sex and age. Przegl Dermatol. 1994;81(5):441-9.

[5]. Pietrzak A, Jastrzębska I, Krasowska D, Chodorowska G, Tabarkiewicz J, Tomasiewicz K, et al. Serum pancreatic lipase [EC 3.1. 1.3] activity, serum lipid profile and peripheral blood dendritic cell populations in normolipidemic males with psoriasis. J Mol Catal B Enzym. 2006 Jun 1;40(3-4):14454.

[6]. Mallbris L, Granath F, Hamsten A, Ståhle M. Psoriasis is associated with lipid abnormalities at the onset of skin disease. J Am Acad Dermatol. 2006 Apr;54(4):614-21. PubMed PMID: 16546581.

[7]. Solak Tekin N, Tekin IO, Barut F, Yilmaz Sipahi E. Accumulation of oxidized low-density lipoprotein in psoriatic skin and changes of plasma lipid levels in psoriatic patients. Mediators Inflamm. 2007;2007:78454. PubMed PMID: 17497039.

[8]. Farshchian M, Zamanian A, Farshchian M, Monsef AR, Mahjub H. Serum lipid level in Iranian patients with psoriasis. J Eur Acad Dermatol Venereol. 2007 Jul;21(6):802-5. PubMed PMID: 17567311.

[9]. Gisondi P, Tessari G, Conti A, Piaserico S, Schianchi S, Peserico A, et al. Prevalence of metabolic syndrome in patients with psoriasis: a hospitalbased case-control study. Br J Dermatol. 2007 Jul;157(1):68-73. PubMed PMID: 17553036.

[10]. Cohen AD, Sherf M, Vidavsky L, Vardy DA, Shapiro J, Meyerovitch J. Association between psoriasis and the metabolic syndrome. Dermatology. 2008;216(2):152-5. doi: 10.1159/000111512. PubMed PMID: 18216477.

[11]. Tam LS, Tomlinson B, Chu TW, Li M, Leung YY, Kwok LW, et al. Cardiovascular risk profile of patients with psoriatic arthritis compared to controls-the role of inflammation. Rheumatology (Oxford). 2008 May;47(5):718- 
23. doi: 10.1093/rheumatology/ken090. PubMed PMID: 18400833.

[12]. Ferretti G, Simonetti O, Offidani AM, Messini L, Cinti B, Marshiseppe I, et al. Changes of plasma lipids and erythrocyte membrane fluidity in psoriatic children. Pediatr Res. 1993 May;33(5):506-9. PubMed PMID: 8511025.

[13]. Rocha-Pereira P, Santos-Silva A, Rebelo I, Figueiredo A, Quintanilha A, Teixeira F. Dislipidemia and oxidative stress in mild and in severe psoriasis as a risk for cardiovascular disease. Clin Chim Acta. 2001 Jan;303(1-2):339. PubMed PMID: 11163020.

[14]. Akhyani M, Ehsani AH, Robati RM, Robati AM. The lipid profile in psoriasis: a controlled study. J Eur Acad Dermatol Venereol. 2007 Nov;21(10):1330-2. PubMed PMID: 17958837.

[15]. Javidi Z, Meibodi NT, Nahidi Y. Serum lipids abnormalities and psoriasis. Indian J Dermatol. 2007 Apr 1;52(2):89.

[16]. Amin T, Saied, E, Abdou SH. Atherosclerotic risk in psoriasis. J Pan-Arab League of Dermatol. 2005;16(2):39-45.

[17]. Bajaj DR, Mahesar SM, Devrajani BR, Iqbal MP. Lipid profile in patients with psoriasis presenting at Liaquat University Hospital Hyderabad. J Pak Med Assoc. 2009 Aug;59(8):512-5. PubMed PMID: 19757693.

[18]. Reynoso-von Drateln C, Martínez-Abundis E, Balcázar-Muñoz BR, BustosSaldańa R, González-Ortiz M. Lipid profile, insulin secretion, and insulin sensitivity in psoriasis. J Am Acad Dermatol. 2003 Jun;48(6):882-5. PubMed PMID: 12789179

[19]. Kumari A, Gowda H. A clinical study of psoriasis and its association with serum lipid profile. metabol. 2017;10:11.

[20]. Naito HK. Coronary artery disease and disorders of lipid metabolism: Clinical chemistry theory analysis co relations. 4th ed. Kaplan LA Peace AJ Kazmierczak SC, Mosby Inc. eds. St louis U.S.A:603; 2003.

[21]. Tietz NW. Clinical guide to laboratory tests. WB Saunders Co; 1995 May 4.

[22]. Matsuzaki Y, Kawaguchi E, Morita Y, Mashige F, Ohisa S, Nakahara K. Evaluation of two kinds of reagents for direct determination of HDL-cholesterol. J Anal Bio-Sc. 1996;19:419-27.

[23]. Beisel WR. Metabolic response to infection. Annu Rev Med. 1975;26:9-20. PubMed PMID: 1096783

[24]. Fiser RH, Denniston JC, Beisel WR. Infection with Diplococcus pneumoniae and Salmonella typhimurium in monkeys: changes in plasma lipids and lipoproteins. J Infect Dis. 1972 Jan;125(1):54-60. PubMed PMID: 4400225 .
[25]. Oppenheim JJ, Cohen S. Interleukins, lymphokines, and cytokines. InProc. 3rd Int. Lymphokine Workshop. Academic Press, Inc., New York 1983 (pp 441-446).

[26]. Dinarello CA. Interleukin-1 and its biologically related cytokines. Adv Immunol. 1989;44:153-205. PubMed PMID: 2466396.

[27]. Feingold KR, Soued M, Adi S, Staprans I, Neese R, Shigenaga J, et al. Effect of interleukin-1 on lipid metabolism in the rat. Similarities to and differences from tumor necrosis factor. Arterioscler Thromb. 1991 MayJun;11(3):495-500. PubMed PMID: 2029492.

[28]. Gyulai R, Kemény L. The immunology of psoriasis: from basic research to the bedside. Orv Hetil. 2006 Nov 19;147(46):2213-20. PubMed PMID: 17396393.

[29]. Coimbra S, Oliveira H, Reis F, Belo L, Rocha S, Quintanilha A, et al. Circulating levels of adiponectin, oxidized LDL and C-reactive protein in Portuguese patients with psoriasis vulgaris, according to body mass index, severity and duration of the disease. J Dermatol Sci. 2009 Sep;55(3):202-4. doi: 10.1016/j.jdermsci.2009.05.008. PubMed PMID: 19576730

[30]. Im SS, Yousef L, Blaschitz C, Liu JZ, Edwards RA, Young SG, et al. Linking lipid metabolism to the innate immune response in macrophages through sterol regulatory element binding protein-1a. Cell Metab. 2011 May 4;13(5):540-9. doi: 10.1016/j.cmet.2011.04.001. PubMed PMID: 21531336.

[31]. Piskin S, Gurkok F, Ekuklu G, Senol M. Serum lipid levels in psoriasis. Yonsei Med J. 2003 Feb;44(1):24-6. PubMed PMID: 12619171.

[32]. Taheri Sarvtin M, Hedayati MT, Shokohi T, HajHeydari Z. Serum lipids and lipoproteins in patients with psoriasis. Arch Iran Med. 2014 May;17(5):343-6. doi: 0141705/AIM.007. PubMed PMID: 24784863.

[33]. Amer M, Galal A, Amer A. Psoriasis Severity is Affected by T the Lipid Profile in Egyptian Patients. Gynecol Obstet (Sunnyvale). 2015;5(346):21610932.

[34]. Niroumand S, Khajedaluee M, Khadem-Rezaiyan M, Abrishami M, Juya M, Khodaee G, et al. Atherogenic index of plasma (AIP): a marker of cardiovascular disease. Med J Islam Repub Iran. 2015 Jul 25;29:240. PubMed PMID: 26793631.

[35]. El ayachi M, Mziwira M, Vincent S, Defoort C, Portugal H, Lairon D. Lipoprotein profile and prevalence of cardiovascular risk factors in urban Moroccan women. Eur J Clin Nutr. 2005 Dec;59(12):1379-86. PubMed PMID: 16118656. 